\title{
BILATERAL ADRENALECTOMY FOR ADVANCED CARCINOMA OF THE BREAST
}

\author{
Major M. S. OWEN-SMITH, M.S., F.R.C.S., R.A.M.C. \\ The Queen Alexandra Military Hospital, Millbank
}

SUMMARY: A series of 27 bilateral adrenalectomies for advanced breast carcinoma is described. The ages of the patients ranged from 26 to 53 years and 16 were below the age of 40 .

Seven ( 28 per cent) did not respond and died on average after 5 months.

Eighteen ( 72 per cent) responded. Of these, 9 died after an average of 22 months ( 2 lived more than 3 years) and 9 are still alive 1 to 3 years after operation.

The development of the operation is described and the results compared with alternative palliative procedures.

\section{Introduction}

About twenty women who have developed carcinoma of the breast are treated at The Queen Alexandra Hospital, Millbank each year. It is likely that this number represents the majority of all cases which occur in female personnel, dependants and others associated with the Army.

The average age of these patients is naturally lower than that of published series due to the restricted age groups involved. However, youth is of little advantage in combating carcinoma of the breast. It has become apparent from studies in many parts of the world that the overall cure rate has been little affected by all the energetic treatment advocated over the last thirty years. In general terms, all treatment seems to do is to alter the time scale of progression whereby, after a varying period of localisation and quiescence the disease spreads locally to the regional lymph nodes and then to the skeleton and soft tissues.

The early and localised disease can be controlled by surgical methods, and moderate localised extensions by radiotherapy. In the early stages of disseminated disease the use of oestrogens or androgens, or the removal of intrinsic sources of oestrogen by oophorectomy may arrest the progress of the disease temporarily. Sooner or later the relentless progression leads to the condition of widespread carcinomatosis.

This small group of women, most of them in the prime of life, with extensive family responsibilities and with an acute awareness of the disastrous situation they are in, need further help. They are often in great pain from bone secondaries, they may have offensively ulcerating local lesions and they sometimes have distressing pleural effusions or multiple skin nodules. Most are house bound or hospitalised and some are bed ridden.

It is this group that presents a problem, not only therapeutically but on humanitarian grounds.

\section{Results}

There were 27 patients who underwent bilateral adrenalectomy and oophorectomy and their ages ranged from 26 to 53 years. The distribution is shown in Fig. 1 and it will be seen that 16 of the patients (60 per cent) were below the age of 40 . 


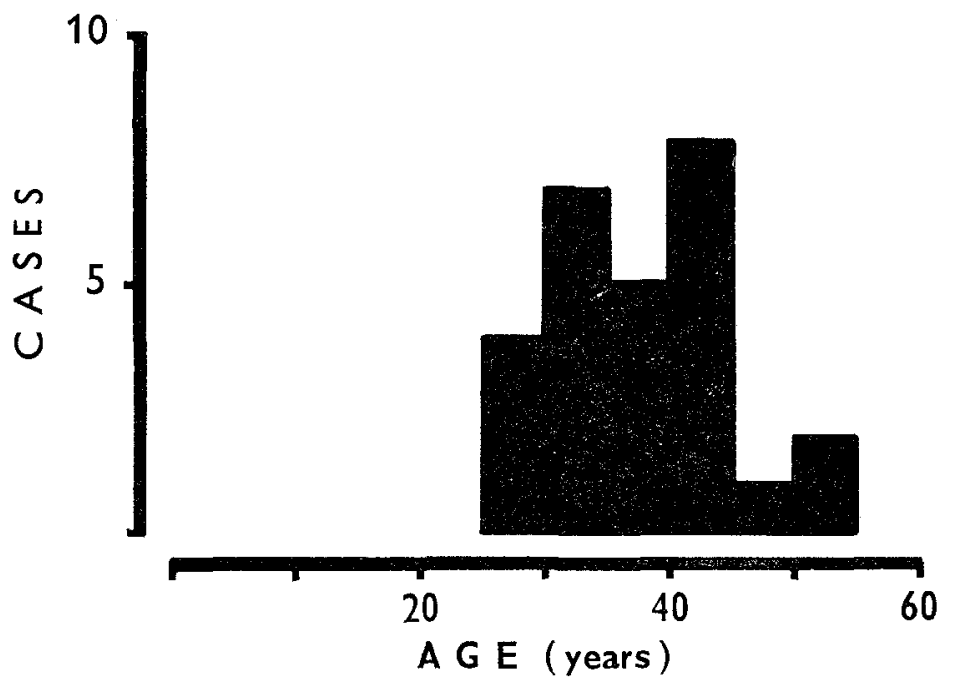

Illustration by courtesy of the University of Manchester Department of Medical Illustration Fig. 1. Age distribution of 27 patients who underwent bilateral adrenalectomy and oophorectomy.

The response to the operation has been classified as Good, Fair or Poor. This classification is based on objective signs of improvement such as regression of primary growth, sclerosis of bone secondaries and the disappearance of soft tissue secondaries, or on marked subjective improvement of symptoms such as pain, breathlessness and lassitude. The results are shown in Table I.

Table I

Summary of results in 27 cases

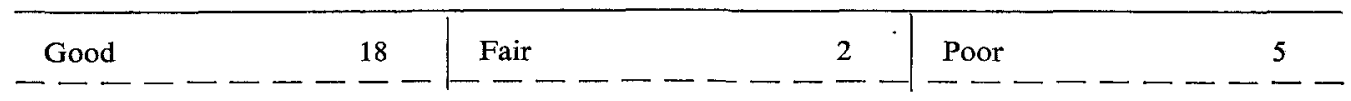

In 2 other cases the follow up has been less than six months.

There were 7 ( 28 per cent) non-responders who are all dead, They survived an average of 5 months.

There were 18 (72 per cent) responders. Of these 9 are already dead, but they survived on average 22 months and 2 of them survived for more than 3 years. Nine are still alive, 5 for more than 2 years and 2 others more than 1 year.

The survival times of the 16 patients who died are shown in Fig. 2.

The excised adrenals were shown to be involved by secondary deposits in 30 per cent. This is similar to the figures of Huggins and Dao (1953) - 30 per cent, Mye and Neal (1965)-33 per cent and Fraccia, Randall and Farrow (1967)—29 per cent.

In many cases the patients experienced almost immediate reduction of pain from bone secondaries, and a number of those classified as non-responders nevertheless developed a well marked euphoria and claimed that they felt better than before operation.

Out of the responders group may be drawn a smaller group of those who have 


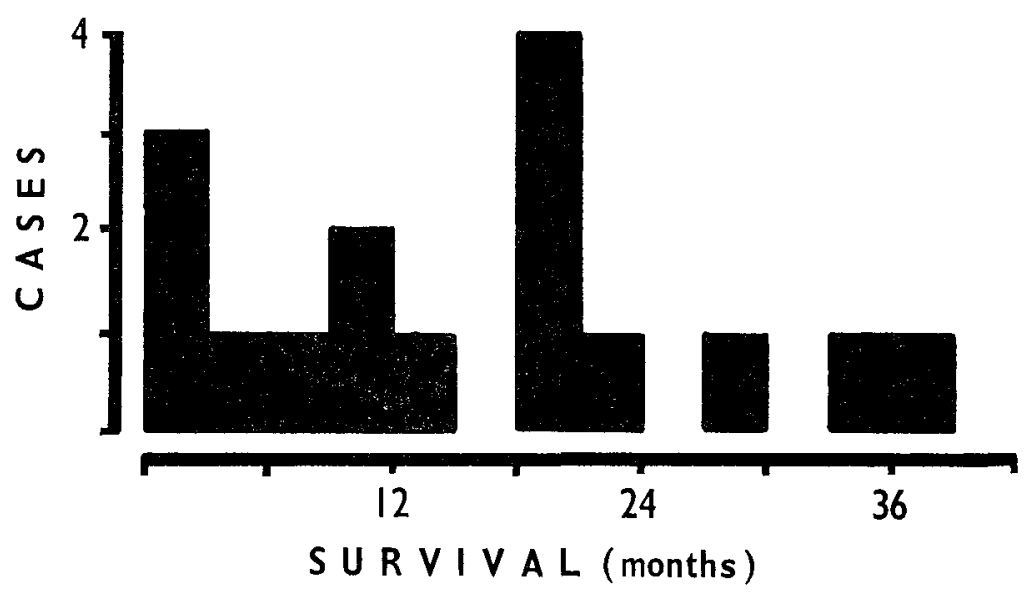

Illustration by courtesy of the University of Manchester Department of Medical Ilustration.

Fig. 2. Survival time of 16 patients who died after bilateral adrenalectomy and oophorectomy.

had a survival of more than 2 years. These are shown in Table II. The only common factor in these cases is that the secondary deposits were mainly in bone and soft tissue. Some of these responses were dramatic. For example:-

Table II

Long term survivals

\begin{tabular}{|c|c|c|c|}
\hline $\begin{array}{c}\text { Case } \\
\text { Number }\end{array}$ & $\begin{array}{l}\text { Survival } \\
\text { in years }\end{array}$ & Initial treatment & Type of metastases \\
\hline $\begin{array}{r}2 \\
7 \\
9 \\
11 \\
14 \\
15 \\
17 \\
18 \\
20\end{array}$ & $\begin{array}{l}3 \\
3 \\
2 \frac{1}{4} \\
3^{*} \\
2 \frac{1}{2} * \\
2 \frac{1}{2} * \\
2 \frac{1}{2} * \\
2 \frac{1}{4} * \\
2^{*}\end{array}$ & $\begin{array}{l}\text { Radical mastectomy } \\
\text { Radical mastectomy } \\
\text { Radical mastectomy } \\
\text { Radical mastectomy } \\
\text { Extended simple mastectomy } \\
\text { Radical mastectomy } \\
\text { Radical mastectomy } \\
\text { Radiotherapy } \\
\text { Radiotherapy }\end{array}$ & $\begin{array}{l}\text { Bone } \\
\text { Bone, soft tissue } \\
\text { Soft tissue } \\
\text { Bone, pleura, liver } \\
\text { Soft tissue } \\
\text { Bone } \\
\text { Bone } \\
\text { Bone, soft tissue } \\
\text { Bone, soft tissue }\end{array}$ \\
\hline
\end{tabular}

* Indicates that the patient is still surviving.

Case 11. Aged 45 years. Had multiple bone secondaries in pelvis, spine and ribs and a pleural effusion. At operation she was noted to have secondaries in the liver. She made a remarkable recovery and remained well for 3 years, at which time she has had further radiotherapy to sclerosed secondaries of the spine and hip for local pain (Figs. 3 and 4). Case 15. 35 years old at time of radical mastectomy. 2 years later had very widespread secondaries in bone. She was bed ridden and in constant severe pain. After operation she was able to get up and walk out of hospital. The secondaries have sclerosed and $2 \frac{1}{2}$ years later she is leading a normal life (Figs. 5, 6 and 7).

The 16 cases who were under 40 years of age responded in similar fashion to those over that age. Five non-responders died after an average of $3 \frac{1}{2}$ months. Two responders died at average 15 months, 9 are still alive, 3 for more than 2 years, 3 more than 1 year and 3 less than 1 year. 


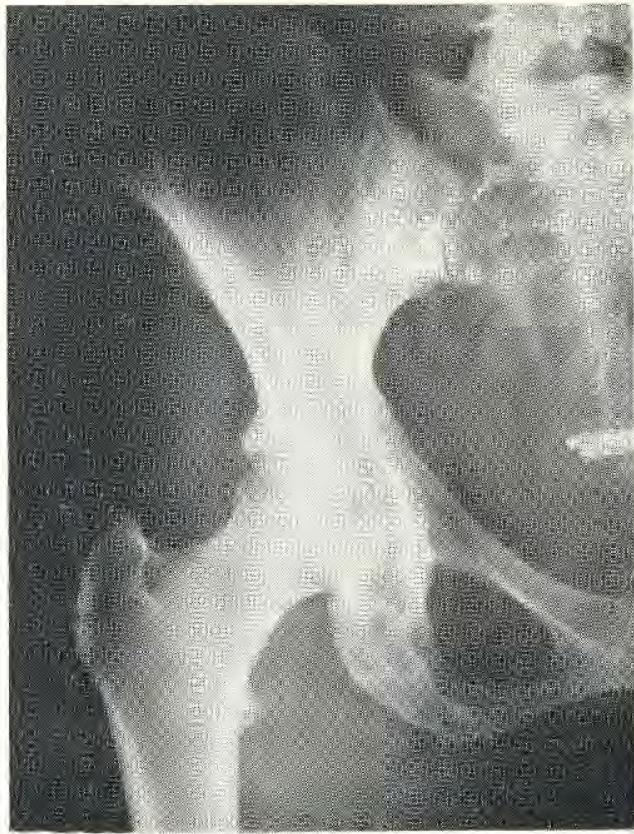

Fig. 3. Case 11. Secondary deposits in ilium and ischio-pubic ramus at time of adrenalectomy.

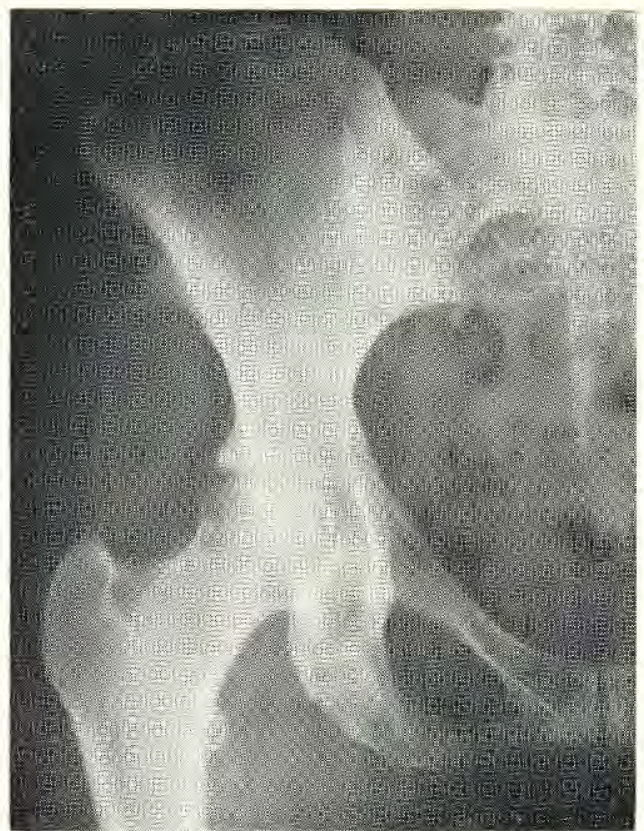

Fig. 4. Case 11. Sclerosis and healing of secondary deposits in ilium and ischio-pubic ramus 2 years after adrenalectomy.

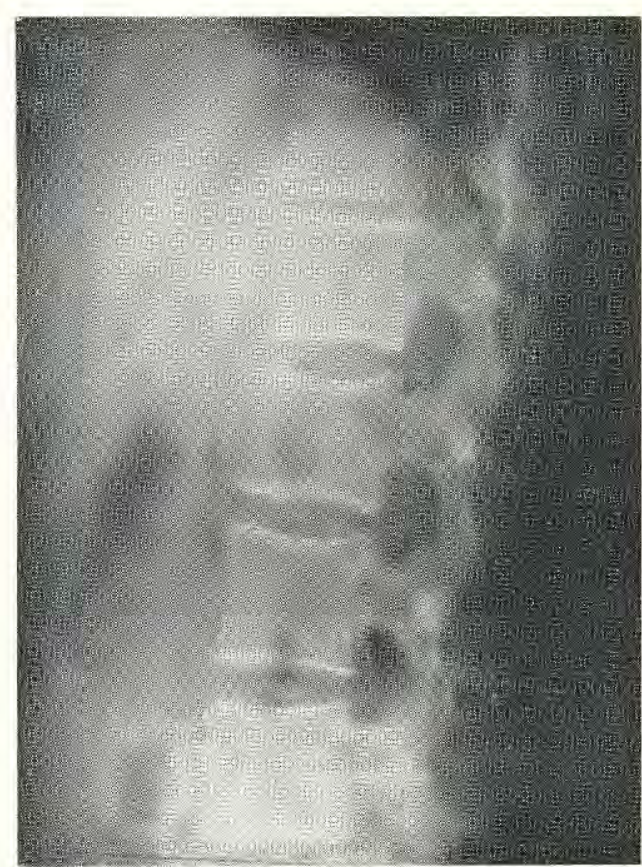

Fig. 5. Case 15. Normal lumbar vertebrae at time of radical mastectomy.

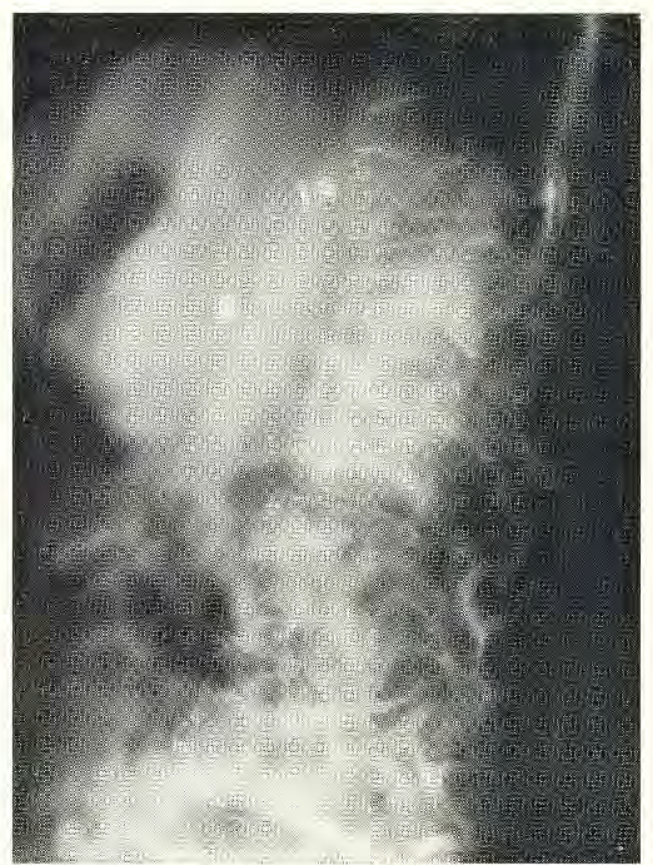

Fig. 6. Case 15. Gross involvement of lumbar vertebrae with secondary deposits at time of adrenalectomy. 


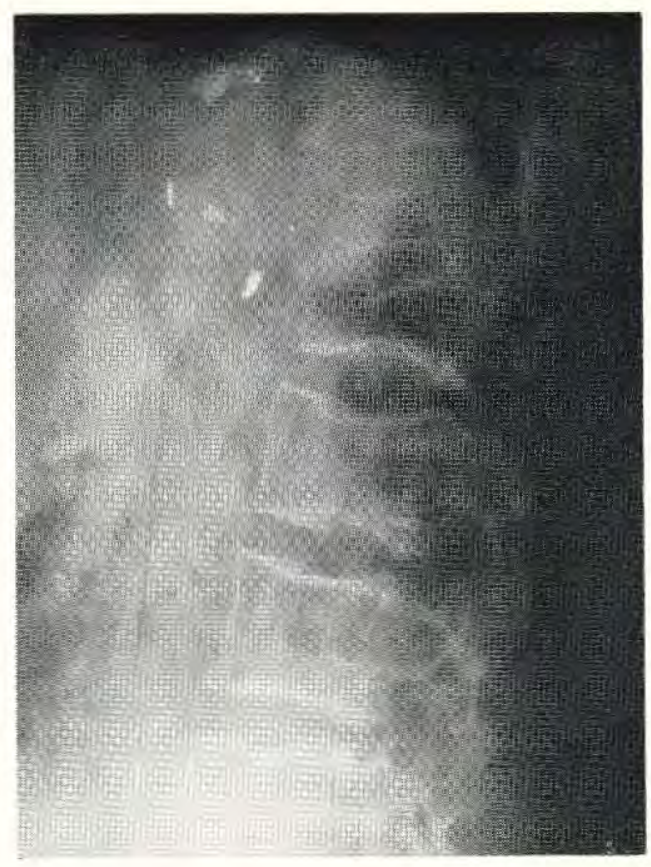

Fig. 7. Case 15. Sclerosis of secondary deposits in lumbar vertebrae with healing of pathological compression fractures.

\section{Oophorectomy}

The beneficial effect on advanced breast carcinoma in altering the endocrine environment was first demonstrated by Beatson in 1896. He removed the ovaries of two patients who had advanced disease with metastases and brought about a good but temporary remission. This advance in treatment was brought into some disrepute because it was used alone as treatment in early breast carcinoma. It was adopted however for advanced cases when surgery was not possible and by 1905 Lett was able to report on 99 cases, of whom 23 were much improved and 13 a little improved. At that time the rationale for such therapy was unknown, and oophorectomy was performed because it appeared effective.

Over the years many such cases responded to oophorectomy only to relapse later, and it became apparent, in the nineteen twenties as steroid metabolism was becoming understood, that there were other sources of oestrogens and androgens. These were finally traced to the adrenal glands and although theoretically it was thought that their removal might benefit patients with advanced carcinoma, the insuperable problem at that time was that adrenalectomy resulted in an Addisonian crisis and death.

Huggins and Dao (1953) showed that in animals oophorectomy reduced the incidence of breast carcinomata but that it was followed by adrenal cortical hyperplasia and the re-appearance of breast tumours.

It was known that bilateral oophorectomy produced a remission in 20 to 30 per cent of cases (Taylor 1962) and it was thought that the removal of the remaining source of endogenous oestrogen should produce further delay in the progression of breast carcinoma. 


\section{The adrenals and adrenalectomy}

The adrenal glands were first described by Eustachius in 1563. Little more was known about them until 1855 when Thomas Addison described their atrophy or destruction in the disease which bears his name.

Brown-Sequard in 1856 demonstrated that bilateral adrenalectomy in laboratory animals always caused their death, and surmised that they produced a secretion which was necessary to maintain life.

In 1936 Reichstein reported the isolation of adrenocortical hormones from the adrenal gland. A partial synthesis was completed in 1946 and total synthesis was achieved in 1951 (Feiser and Feiser, 1959).

In 1945 Huggins and Scott reported the first patient to survive following bilateral total adrenalectomy. The operation was done for the palliation of advanced prostatic carcinoma, and he survived for 4 months on a regime of adrenal cortex extract and desoxycorticosterone acetate planned by Professor Thom.

Huggins and Bergenstal (1951) reported other cases in which bilateral adrenalectomy had been tried in the late nineteen forties without success in spite of attempts at replacement therapy. Independantly Atkins in 1947 did bilateral subtotal adrenalectomy and bilateral oophorectomy on 7 patients with advanced breast carcinoma.

When cortisol became available the consequent increase in survival rates, following destruction or removal of the adrenals, by adequate replacement therapy was dramatic. It gave great impetus to the use of the operation for the palliation of advanced breast carcinoma. The rationale of removing the adrenals, as well as the ovaries, was the elimination of all known sources of hormones which could influence the growth of breast carcinoma.

The operation was usually done as a staged procedure, one adrenal being removed by a postero-lateral approach with bilateral oophorectomy at the same time, and the other adrenal being removed later.

In 1955 Aird and Helman described bilateral adrenalectomy done by an anterior approach. The patient was placed supine and an incision was made parallel to the right costal margin and one hand's breadth below it, this incision was carried over to the left costal margin. The spleen was mobilised and drawn forwards and to the right together with the tail of the pancreas. The upper pole of the kidney was depressed before incising the peritoneum and removing the left adrenal. The right adrenal was then mobilised and removed. They considered that the anterior approach was advantageous because the patient was not turned whilst on the operating table, thus avoiding complications from spine secondaries; the abdomen could be explored thoroughly; both adrenals could be exposed and examined simultaneously, and bilateral oophorectomy could be done through the same incision.

McKeown and Ganguli in 1956 described a modification of this technique using a curved, transverse upper abdominal incision which was convex upwards. They drained the adrenal beds through the lateral edges of the incision.

The advantages of the anterior approach are such that it has now been accepted as the operation of choice for bilateral adrenalectomy for advanced breast carcinoma. Operative mortality fell as experience of the operation accumulated and really terminal patients were excluded. Several useful conclusions were reached from reported series: 
a. The longer the interval between the appearance of the disease and adrenalectomy the greater the chance of response.

b. A good response to oophorectomy suggested a further response to adrenalectomy.

c. It was not possible to forecast accurately which patient would do well.

d. Occasional patients made dramatic responses which were sustained.

The response to adrenalectomy is difficult to evaluate. An objective response might be defined as one in which there is a measurable decrease in size of primary or secondary tumour, or when bone deposits become sclerosed on radiographic appearances. A subjective response is when there is relief of pain and when the patient feels better. Both responses should be for at least 6 months.

The operation rapidly became established and widely practised both in this country and in the United States of America (U.S.A.) so that by 1967 Moore et al were able to report the collected results amounted to 1900 cases. There was a per-operative mortality of 5 to 16 per cent and remission rates of 28 to 45 per cent. Those who responded to the operation survived 18 to 24 months whilst non-responders survived only 6 months.

Personal or institutional series are rather similar. Cade (1957) reported 158 patients with objective improvement in 39 per cent and subjective improvement in 58 per cent. Fraccia, Randall and Farrow (1967) reported a series of 500 consecutive adrenalectomies with an overall remission rate of 35 per cent. Objective improvement was noted in 31 per cent and subjective improvement in 40 per cent. These figures are close to those reported by Byron et al (19\$2), McDonald (1962), Mye and Neal (1965), Dao and Nemoto (1965), Shepard (1966), Delarue et al (1967), Harris and Spratt (1969), Wilson et al (1969) and Safarty (1969).

Adrenalectomy and oophorectomy has to be compared with hypophysectomy as palliative treatment in advanced breast carcinoma. Atkins et al $(1957,1960)$ showed that there was a slight bias in favour of hypophysectomy, but McDonald 1962) in an extensive collection trial in the U.S.A. showed no statistical difference. However, the position since those reports has changed. In the hands of the Guy's Hospital surgeons surgical hypophysectomy has now been established as so significantly superior to adrenalectomy that the latter operation has been more or less abandoned.

In their series a good result was obtained after surgical hypophysectomy in 36 per cent of 70 patients compared with 23 per cent of 77 adrenalectomies, the intermediate response was the same at 30 per cent, and there were 34 per cent of failures as against 47 per cent. The mean survival time following hypophysectomy was 20.2 months compared with 12.2 months for adrenalectomy and in the successful group it was 40.8 and 31.6 months respectively (Atkins 1971).

These must be regarded as exceptional results and in the absence of expert neurosurgical care and availability of time, bilateral adrenalectomy will remain a useful operation in the general surgeon's treatment of women with advanced breast carcinoma.

\section{Discussion}

Is bilateral adrenalectomy and oophorectomy worthwhile? There is no doubt that in nearly three quarters of the patients the operation was well worth doing. There were no deaths as a direct result of the operation. Control of steroid replacement was no problem with most patients being maintained on a dose of 50 to $75 \mathrm{mg}$ a day of cortisone 
acetate, and 6 patients have already survived more than twice their untreated life expectancy with 3 more patients progressing favourably.

It is gratifying to note the response of the younger women. Mye (Mye and Neal 1965) stated that none of his patients under the age of 40 responded favourably to bilateral adrenalectomy and oophorectomy. Harris and Spratt (1969) had only one patient in this age group who responded. Atkins (1971) however confirms that younger women do respond more favourably than published series would indicate.

The type of metastasis has some bearing on the response to be expected. Certainly in this series bone and soft tissue metastases have been controlled best by the operation and this agrees with the conclusions of Huggins and Dao (1953), Harris and Spratt (1969) and others.

However the occasional patient with proven visceral metastases does well as is illustrated by the 3 year plus survival of case number 11 .

What alternatives are there to offer these patients? Taylor (1962) noted that bilateral oophorectomy alone in pre-menopausal women results in an objective remission rate of about 30 per cent but he also noted that in those patients under 35 only 16 per cent responded.

Pyrah and Smiddy (1954) recorded survival times after testosterone as palliative treatment in advanced breast carcinomatosis of 7.5 months, and with oestrogens alone it was 7.5 to 12 months. Dao and Nemoto's (1965) figures for androgens alone was 10 months. Pearson (1967) recorded collected figures of 12 months for oestrogens alone, 6 months for androgens alone and 3 months for corticosteroids. So the average survival times following bilateral adrenalectomy and oophorectomy is better than those alternatives.

One of the reasons for poor response to bilateral adrenalectomy is that not all functioning adrenal tissue is removed. Graham (1953) has reported that in 32 per cent of necropsies accessory adrenal tissue was present.

In conclusion one must say that in those patients with widespread metastatic disease from carcinoma of the breast the operation of bilateral adrenalectomy is well worth doing. It offers a good chance of palliation, with a significant increase in the quality and duration of these patients lives, and occasionally brings about a dramatic relief of distressing symptoms.

\section{REFERENCES}

Aird, I. and Helman, P. (1955). Brit. med. J. ii, 708.

Atkins, H. J. B. (1971). Personal communication.

Atkins, H. J. B., Falconer, M. A., HaYWARD, J. L., and MacLean, K. S. (1957). Lancet i, 489.

Atkins, H. J. B., Falconer, M. A., HaYward, J. L., SchurR, P. H. and Armitage, P. (1960). Lancet i, 1148 .

BeAtSON, G. T. (1896). Lancet ii, 104 and 162.

Byron, R. L., Yonemoto, R. H., Bashore, R., Bierman, H. R., Cronemiller, P. and Masters, H. (1962). Surgery 52, 725.

CADE, S. (1957). Cancer 10, 777.

DAO, T. L., and Nemoto, T. (1965). Surg. Gynec. Obstet. 121, 1257.

Delarue, N. C., Peters, V., Anderson, W. S. and Starr, J. (1967). Canad. med. Ass. J. 96, 637.

FeISER, L. F. and FeISER, M. A. (1959). Steroids. Chapman \& Hall, London.

Fraccia, A. A., Randall, H. T. and Farrow, J. H. (1967). Surg. Gynec. Obstet. 125, 747.

Graham, L. S. (1953). Cancer 6, 149.

HARRIS, H. S. and SPRATT, J. S. (1969). Cancer 23, 145.

HuggiNS, C. and Scort, W. W. (1945). Ann. Surg. 122, 1031. 
Huggins, C. and Bergenstal, D. M. (1951). J. Amer. med. Ass. 147, 101.

Huggins, C. and Dao, T. L. (1953). J. Amer. med. Ass. 151, 1388.

LETT, H. (1905). Lancet i, 227.

MCDonald. I. (1962). Surg. Gynec. Obstet. 115, 215.

McKeown, K. C. and Ganguli, A. (1956). Brit. med. J. i, 1466.

Moore, F.'D., Woodrow, S. I., Aliapoulios, M. A. and WILSON, R. E. (1967). New. Engl. J. Med. 277,293 and 460

MYe, G. C. and NEAL, W. (1965). Ann. Surg. 31, 621.

Pearson, O. H. (1967). Modern Trends in Endocrinology. Vol. 3. Ed. Gardiner-Hill, H. Butterworth, London. P. 242.

Pyrah, L. N. and SMIDDY, F. G. (1954). Lancet i, 1041.

ReICHSTEIN, T. (1936). Helv. chim. Acta. 19, 1107.

SAFARTY, G. (1969). Med. I. Aust. 1, 398.

SHEPHARD, J. A. (1966) J. roy. Coll. Surg. Edinb. 12, 34.

TAYLOR, S. G. (1962). Surg. Gynec. Obstet. 115, 443.

Wilson, R. E., Piro, A. J., Aljapoulios, M. A. and Moore, F. D. (1969). Cancer 24, 1322.

M.S. (Lond.)

F.R.C.S. (Edin.)

F.R.C.S.

(Ophthalmology)

F.R.C.P.(Glas.)

F.F.C.M.

M.R.C.P.

M.R.C.Psych.

M.F.C.M.

M.R.C.O.G.

D.C.H.

D.O.

D.T.M.\&H.

\section{ACADEMIC ACHIEVEMENTS}

MAJOR N. A. BOYD, M.B., B.S., F.R.C.S., D.T.M.\&H., R.A.M.C.

Lieutenant-Colonel M. A. R. Eslick, M.B., ch.B., R.A.M.C.

MAJOR A. G. MurPhY, M.B., Ch.B., M.R.C.S., L.R.C.P., D.O., R.A.M.C.

Lieutenant-Colonel R. A. Dunbar-Miller, M.B., B.S., F.R.C.P.(Edin.), F.R.F.P.S., M.R.C.P., D.P.M., D.T.M.\&H., R.A.M.C.

Brigadier T. W. CARRICK, O.B.E., M.B., Ch.B., D.P.H., D.I.H., late R.A.M.C.

MAJOR G. W. KeMBER, M.B., Ch.B., D.obst.R.C.O.G., D.C.H., R.A.M.C.

LieUtenANT-COLONEL P. ABRAHAM, M.R.C.S., L.R.C.P., D.P.M., D.T.M.\&H., R.A.M.C. MAJOR D. W. LAURIE, M.B., Ch.B., M.R..C.S., L.R.C.P., D.P.M., D.obst.R.C.O.G., R.A.M.C.

COLONEL H. R. MILLER, M.R.C.S., L.R.C.P., D.T.M.\&H., D.P.H., late R.A.M.C. Colonel T. B. HaRrison, M.B., Ch.B., D.P.H., late R.A.M.C. COLONEL A. J. Moss-BLundell, M.B.E., M.A., M.B., B.chir., D.P.H., D.T.M.\&H., late R.A.M.C. Colonel T. C. R. ARCheR, M.B., B.S., D.P.H., D.I.H., late R.A.M.C. COLONEL D. G. MILNE, M.B., Ch.B., D.P.H., late R.A.M.C. Colonel W. S. MILlar, L.R.C.P., L.R.C.S., D.r.H., D.P.H., D.T.M.\&H., late R.A.M.C. ColoneL H. F. MCELligot, M.B., B.ch., D.P.H., D.I.H., D.T.M.\&H., late R.A.M.C. COLONEL J. G. P. POWER, M.B., B.Ch., D.P.H., D.I.H., D.T.M.\&H., late R.A.M.C. COLONEL T. S. HART, M.B., B.S., D.P.H., D.T.M.\&H., late R.A.M.C. LIEUTENANT-COLONEL D. H. MCFERRAN, M.B., B.S., D.P.H., D.I.H., D.T.M.\&H., R.A.M.C. LJEUTENANT-COLONEL W. M. CORNELIUS, L.M.S.S.A., D.P.H., D.J.H., D.T.M.\&H., R.A.M.C. LIEUTENANT-COLONEL W. J. LAWRENCE, M.R.C.S., L.R.C.P., D.P.H., D.I.H., D.T.M.\&H., R.A.M.C. MAJOR J. QUINN, B.A., M.B., B.Ch., D.P.H., D.I.H., D.T.M.\&H., R.A.M.C.

Major B. A. E. Chapman, M.B., Ch.B., D.obst.R.C.o.G., R.A.M.C. Major H. MARTIN, M.B., Ch.B., D.obst.R.C.O.G., R.A.M.C.

Major T. Graham, M.B., B.Ch., R.A.M.C.

CAPTAIN B. HOPKISSON, M.A., M.B., B.chir., R.A.M.C.

Major H. C. Mason, m.B., Ch.B., r.A.M.C. Major K. H. H. Young, M.B., B.Ch., D.P.H., R.A.M.C. 